\title{
PENYULUHAN KESEHATAN MENTAL DI MASA PANDEMI COVID-19
}

\author{
Surya Syarifuddin'1), Nur Afni Ponseng1) \\ 1)Program Studi S1 Farmasi, Fakultas Farmasi, Universitas Megarezky, Makassar, Sulawesi Selatan, Indonesia \\ Corresponding author : Surya Syarifuddin \\ E-mail : suryasyarifuddin@gmail.com
}

\section{Diterima 30 November 2021, Disetujui 04 Desember 2021}

\begin{abstract}
ABSTRAK
Penyebaran virus Covid-19 telah menjadi pandemi di Indonesia, menyebabkan bencana bagi masyarakat dan mengakibatkan kematian diseluruh dunia. Berbagai dampak yang terjadi seperti adanya perubahan pada bidang sosial, bidang ekonomi dan bidang psikologis. Dampak pada bidang psikologis diantaranya seperti orang yang merasakan cemas, takut, depresi, khawatir akan tertular hingga adanya keinginan bunuh diri, gangguan perasaan tersebut harus dikelola dengan baik agar tidak memberikan dampak pada kesehatan mental. Tujuan pelaksanaan kegiatan ini adalah meningkatkan pengetahuan masyarakat tentang kesehatan mental di masa pandemi Covid-19. Metode yang digunakan adalah penyuluhan kesehatan dengan mengunakan media poster. Hasil pelaksanaan kegiatan ini yaitu masyarakat paham akan isi pesan yang tercantum di dalam poster dan adanya keinginan untuk mengubah sikap untuk tetap menjaga kesehatan mentalnya di masa pandemi Covid19. Kesimpulannya bahwa kegiatan ini dapat meningkatkan pengetahuan dan kesadaran masyarakat untuk menjaga kesehatan mental di masa pandemi Covid-19.
\end{abstract}

Kata kunci: kesehatan mental; pandemi; covid-19.

\begin{abstract}
The Covid-19 virus has become a pandemic in Indonesia. Causing harm for the community and resulting death throughout the world. Various effects that occur such as changes in the social, economic, and psychological fields. Psychological disorders that felt include feeling sad, fearful, depressed, worring about being infected, and suicidal ideation have an influence on mental health. These feelings disorders must be managed properly so that they do not have an impact on mental health. The purpose of this activity is to increase public knowledge about mental health during the Covid-19 pandemic. The method used is health education with poster media. The result is that the public understands the contents of the message contained in the poster and there is a desire to change attitudes to maintain their mental health. The conclusion is that this activity can improve public knowledge and awareness to increasing mental health during the Covid-19 pandemic.
\end{abstract}

Keywords: mental health; pandemic; covid-19.

\section{PENDAHULUAN}

Penyebaran virus Covid-19 telah menjadi pandemi di Indonesia, menyebabkan bencana bagi masyarakat dan mengakibatkan kematian diseluruh dunia. Sejak bulan Maret hingga bulan Juni 2020 tercatat sudah 40.400 kasus positif Covid-19 di Indonesia. Berbagai dampak yang terjadi selama mewabahnya virus Covid-19 seperti adanya perubahan pada bidang sosial, bidang ekonomi dan bidang psikologis. Dampak pada bidang psikologis diantaranya seperti orang yang merasakan cemas, takut dan khawatir akan tertular Covid19, perasaan tersebut harus dikelola dengan baik agar tidak memberikan dampak pada gangguan kesehatan mental. Dampak kasus gangguan kesehatan mental yang dapat berupa stress hingga depresi dan akan membahayakan jika tidak ditangani dengan benar. Dengan memberikan informasi berupa pengetahuan dan konseling pada mereka yang bergejala mengidap gangguan kesehatan mental dan memberikan sosialisasi sangatlah diperlukan di masa pandemi ini.

Masalah kesehatan mental di Indonesia butuh perhatian yang serius, yakni dimulai melakukan perubahan untuk menekan angka kejadian. Permasalahan di Indonesia pada penanganan kesehatan mental ialah masih kurangnya edukasi terkait kesehatan mental. Pemberian informasi terkait kesehatan mental sangat penting untuk diberikan karena terkait dengan kehidupan sehari-hari pada masyarakat dan untuk keberhasilannya dengan memberikan support satu sama lain sebagai upaya menjaga kesehatan bersama. 
Kesehatan ialah bagian penting perlu diperhatikan dan dijaga, mencakup kesehatan fisik, kesehatan mental dan kesehatan sosial, pencapaian untuk menuju kondisi kesehatan yang harmonis merujuk pada bagagaimana individu mampu membiasakan diri serta berinteraksi dengan lingkungan sekellingnya. Kesehatan mental masing-masing individu bebeda dan selalu mengalami dinamisasi pada setiap kemajuannya. Pada hakikatnya manusia dihadapkan pada situasi wajib menuntaskan permasalahannya dengan berbagai alternatif. Seorang dikatakan mempunyai kemampuan adaptasi diri yang baik apabila sanggup menyelesaikan kesulitan serta masalah yang dihadapinya, dengan cara yang baik dan tidak membebani diri sendiri, lingkungannya, serta cocok dengan norma soial serta agama (Fakhriyani, 2019).

Maraknya informasi seputar Covid-19 yang disebarkan melalui media televisi, media sosial, dan berbagai media lainnya, mengenai banyaknya korban jiwa akibat pandemi ini, menimbulkan adanya kekhawatiran yang berlebih. Gangguan mental seperti mudah terbawa emosi, menimbulkan stress, cemas, dan depresi yang akan mempengaruhi ketidakseimbangan fungsi otak yang berdampak pada gangguan psikis atau ganguan kejiwaan. Ketika seseorang mengalami gejala psikis atau gangguan kejiwaan akan membuat seseorang dapat merasakan gejala-gejala seperti gejala penyakit virus Covid-19, seperti merasakan demam, mual, pusing, sakit tenggorokan.

Banyaknya kasus infeksi Covid-19 menyebabkan masyarakat tinggal dirumah, melakukan berbagai aktivitas di rumah dan melakukan pembatasan sosial di luar rumah sehingga menyebabkan gangguan mental.

Gangguan emosional menurut (Nurjanah, 2020) disebabkan oleh beberapa faktor seperti adanya perasaan cemas, tegang atau khawatir, aktivitas sehari-hari menjadi terbengkalai, menurunnya nafsu makan dan tidur kurang nyeyak.

Selain itu adanya ketidakpastian kapan berakhirnya pandemi Covid-19, adanya social distancing, isolasi, pandangan buruk dan diskriminasi terhadap penderita juga adanya masalah kesulitan ekonomi serta adanya perubahan pola kebiasaan yang biasanya bekerja dan beraktivitas di luar rumah sekarang semuanya harus dilakukan di dalam rumah sehingga perlu adaptasi kebiasaan baru yang dapat memberikan efek mempengaruhi kesehatan mental masyarakat.

Berdasarkan data Swaperiksa yang diperoleh Perhimpunan Dokter Spesialis Kedokteran Jiwa Indonesia (PDSKJI) pada bulan April hingga Agustus 2020, terdapat 3.443 orang melakukan swaperiksa ternyata mengeluhkan masalah psikologis. Sebanyak 16 persen yang megalami masalah trauma psikologis, sebanyak 47.9 menunjukkan gejala kecemasan, dan 36.1 meninjukkan adanya gejala depresi. Kejadian ini ternyata lebih tinggi 5-6 kali apabila dibandinkan dengan angka kejadian depresi berdasarkan Riset Kesehatan Dasar tahun 2018, dan lebih besar dibandingkan dengan kajadian depresi pada bencana non-pandemi lain. (Wahyuni, 2020)

Kementerian Kesehatan mencatat selama pandemi Covid-19, hingga Juni 2020, ada sebanyak 277 ribu kasus kesehatan jiwa di Indonesia. Jumlah kasus kesehatan jiwa itu mengalami peningkatan dibandingkan 2019 yang hanya 197 ribu orang. Adanya peningkatan kasus kesehatan jiwa di masa pandemi tersebut akibat terbatasnya akses dan permasalahan sosial yang dialami masyarakat sehingga mereka mengalami depresi. (Susanto, 2020)

Pelaksanaan kesehatan mental yang dilakukan di rumah, sekolah, tempat kerja dan lingkungan sekitar seperti sikap hangat dari keluarga, pemberian kasih sayang dan perhatian serta penghargaan dapat meningkatkan jalinan interpersonal yang baik yang kemudian menciptakan suasana kondusif yang mampu mendukung perkembangan kesehatan mental (Fakhriyani, 2019).

Dalam penanganan kesehatan mental membutuhkan banyak dukungan dari berbagai pihak, baik pemerintah, nonpemerintah semuanya harus saling bekerjasama untuk pencapaiannya. Dibutuhkan peran pada semua pemangku kepentingan untuk mencapai masyarakat yang memiliki kesehatan mental yang baik selama masa pandemi Covid-19. Oleh karena itu untuk mendukung terciptanya kesehatan mental yang baik sehingga dilakukan penyuluhan kesehatan metal di masa pandemi Covid-19 dengan harapan mampu meningkatkan kesadaran masyarakat untuk mampu mengelola dan kesehatan mentalnya di masa pandemi ini.

\section{METODE}

Metode yang digunakan dalam pelaksanaan pengabdian kepada masyarakat adalah diskusi dan penyuluhan dengan menggunakan media poster kepada masyarakat di Kelurahan Manggala Kecamatan Manggala. Metode yang dilakukan ada beberapa tahapan :

1. Melakukan observasi lapangan untuk melihat dan mengumpulkan data/informasi terkait kondisi di lapangan yang berguna 
dalam mendukung kegiatan penyuluhan yang akan dilakukan dan

2. Melakukan diskusi dengan tim pelaksana terkait agenda kegiatan pengabdian dan pembahasan mengenai isi pesan penyuluhan yang akan dicantumkan pada poster.

3. Pembuatan poster, media poster bertujuan untuk memberikan informasi, mengajak dan menghimbau serta menyuruh masyarakat untuk mengikuti sesuai apa yang tertera pada poster. Isi dari poster mengandung informasi yang mudah dimengerti, warna yang digunakan dalam pembuatan poster ialah warna yang terang agar pembaca tertarik untuk melihat, menggunakan kalimat yang singkat, padat, dan jelas agar mudah dipahami oleh pembaca.

4. Publikasi poster, penyebaran poster dilakukan di tempat-tempat umum seperti di pasar, di toko atau di warung serta tempat strategis yang dapat dibaca dan dilihat oleh masyarakat.

\section{HASIL DAN PEMBAHASAN}

Kegiatan pengabdian kepada masyarakat tentang penyuluhan kesehatan mental di masa pandemi Covid-19 dilaksanakan pada bulan Juni-Juli 2021 dengan sasaran pada masyarakat yang berada di lokasi wilayah Kelurahan Manggala Kecamatan Manggala. Pada pelaksanaan kegiatan pengabdian masyarakat ini terbagai atas tiga tahap pelaksanaan yakni tahap sebelum penyuluhan, tahap pelaksanaan penyuluhan dan tahap setelah penyuluhan.

\section{Tahap Sebelum Penyuluhan}

Pada tahapan kegiatan yang pertama adalah melakukan observasi gunanya untuk mengamati perilaku masyarakat dan melihat fenomena serta memperhatikan kondisi dilapangan guna mendapatkan informasi yang bermanfaat pada kegiatan penyuluhan seperti mempelajari perilaku manusia yang menjadi target penyuluhan, kemudian setelah ini berdiskusi dengan tim terkait dengan pelaksanaan kegiatan dan isi pesan yang akan dicantumkan pada poster penyuluhan kesehatan mental di masa pandemi Covid-19.

\section{Tahap Pelaksanaan Penyuluhan}

Kegiatan pengabdian ini dilaksanakan dengan melalui penyuluhan kesehatan mental dengan menggunakan media poster, hal ini disebabkan metode poster merupakan metode yang efektif pada saat terjadinya pandemi Covid-19 yang mengurangi kerumunan masyarakat dan adanya upaya menjaga jarak sehingga aturan protokol kesehatan tetap dipatuhi guna menghindari penularan virus Covid-19.

Pada dasarnya poster merupakan suatu media yang lebih menekankan kekuatan pesan, visual, dan warna untuk dapat mempengaruhi perilaku dan sikap seseorang. Seperti media cetak pada umunya, poster dapat mempermudah dan mempercepat pemahaman terhadap pesan yang disajikan, dilengkapi dengan warna-warni sehingga dapat menarik perhatian, bentuknya sederhana tanpa memrlukan peralatan khusus dan mudah penempatannya , sedikit memerlukan informasi tambahan serta pembuatanya mudah dan harganya yang terjangkau(Sumartono \& Hani, 2018).

Selain itu menurut Kholid (2015:138) bahwa poster merupakan pesan singkat dalam bentuk gambar dengan tujuan untuk mempengaruhi seseorang agar tertarik pada sesuatu, atau mempengaruhi seseorang bertindak sesuai dengan apa yang dipahaminya. Poster merupakan media yang lebih diutamakan dalam promosi kesehatan karena lebih dekat dan detail (Kholid, 2015)

Selain itu menurut (Kayyis et al., 2020) bahwa bahwa poster adalah salah satu bentuk media informasi yang banyak digunakan untuk menyambpaikan informasi, digunakan untuk menyampaikan pesan-pesan kesehatan. Apabila dengan membaca poster dengan berulang-ulang maka informasi yang tertera pada poster tersebut dapat dipahami dan mempengaruhi serta memotivasi untuk mengikuti informasi yang terdapat didalamnya (Ulya \& Iskandar, 2017)

Penyebaran poster ini dilakukan di tempat-tempat umum seperti Kandungan isi yang tercantum pada poster berisi informasi untuk mengedukasi masyarakat untuk menjaga kesehatan mentalnya selama pandemi Covid19 terjadi.

Dalam upaya meningkatkan derajat kesehatan masyarakat, pemerintah telah melakukan berbagai kegiatan, salah satu upaya yang dilaksanakan ialah program dalam menjaga mental selama terjadinya pandemi yakni memberikan edukasi terkait bagaimana menjaga kesehatan mental di masa pandemi Covid-19. Oleh karena itu untuk mendukung kebijakan pemerintah perlu diadakan kegiatan penyuluhan kepada masyarakat.

Ciri-ciri mental yang sehat menurut World Health Organisation ialah memiliki kemampuan belajar dari pengalaman, dapat menyesuaikan diri, senang berbagi daripada menerima, senang membantu, dapat memberikan rasa sayang, sanggup mengolah 
kesedihan dan menjadikan masalah sebagai pengalaman, senantiasa selalu berfikir positif.

isi pesan yang ada dalam poster sebagai berikut :

1. Melakukan Aktivitas Fisik

2. Mengkonsumsi Makanan Bergizi

3. Mencukupkan Waktu Tidur

4. Membatasi Diri untuk Mengakses Informasi Terkait Covid-19

5. Menjalin Komunikasi dengan Keluarga dan Sahabat

6. Menjaga Tetap Aktif dan Produkif Penyampaian Informasi yang termaktub dalam isi poster merupakan upayaupaya yang perlu dilakukan untuk tetap menjaga kesehatan mental selama pandemi Covid-19 kemudian poster ditempelkan di dinding rumah dan tempat umum lainnya agar masyarakat yang lain dapat yang melihat poster tersebut seperti pada gambar 1 .
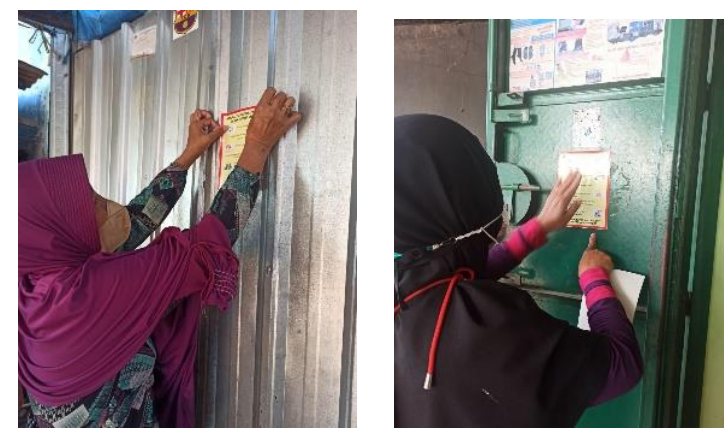

Gambar 1. Pemasangan Poster Penyuluhan Kesehatan Mental

\section{Tahap Setelah Penyuluhan}

Selama kegiatan penyuluhan berlangsung, masyarakat senang dengan adanya kegiatan ini, sebagaimana terlihat minat masyarakat dalam keikutsertaan dalam pelaksanaan penyuluhan kesehatan mental ini. Kesadaran masyarakat akan pentingnya menjaga kesehatan mental pada saat pandemi ini mempermudah dalam melaksanakan pengabdian ini. Pemahaman akan kesehatan mental memberikan dampak positif pada masyarakat sehingga kesehatan mental dapat terjaga dengan baik.

Setelah kegiatan penyuluhan dilaksanakan sebagaian besar senang dan paham dengan poster karena tertarik dengan isi pesan dalam posternya serta perpaduan warna dari posternya dan warna yang cerah membuat masyarakat memberi perhatian untuk membacanya. Masyarakat juga tertarik dengan informasi yang diberikan karena penyuluhan kesehatan ini merupakan masalah yang dialami saat ini yakni adanya pandemi virus Covid-19. Pelaksanaan kegiatan pengabdian masyarakat ini memberikan manfaat yang signifikan pada masyarakat yang berada di wilayah Keluraha
Manggala Kecamatan Manggala. Dengan adanya penyuluhan ini dapat mengedukasi dan mempengaruhi perilaku masyarakat agar tetap menjaga kondisi kesehatan mental di masa pandemi Covid-19.

\section{SIMPULAN DAN SARAN}

Kegiatan ini dirasa sangat penting karena dapat meningkatkan pengetahuan dan kesadaran masyarakat untuk menjaga kesehatan mental di masa pandemi Covid-19 dan sangat bermanfaat serta perlu dilakukan di lingkungan masyarakat yang lebih luas.

\section{UCAPAN TERIMAKASIH}

Ucapan terima kasih kepada LPPM yang memberikan amanah dalam kegiatan pengabdian ini serta masyarakat di lingkungan Keluarahan Manggala Kecamatan Mangggala atas keikutsertaannya dalam penyuluhan kesehatan mental di masa pandemi Covid-19.

\section{DAFTAR RUJUKAN}

Fakhriyani, V. D. (2019). Kesehatan Mental. Pamekasan : Duta Media Publishing.

Kayyis, R., Rosidah, A., \& Khasanah, B. A. (2020). Penyuluhan Masyarakat Desa Sadar Covid 19 Melalui Poster. Abdimas Siliwangi, 04(01), 129-137.

Kholid, A. (2015). Promosi Kesehatan dengan Pendekatan Teori Perilaku, Media, dan Aplikasinya. Rajawali Press.

Nurjanah, S. (2020). Gangguan Mental Emosional Pada Klien Pandemi Covid 19 di Rumah Karantina. Journal IImu Keperawatan Jiwa, 3(3), 329-334.

Sumartono, \& Hani, A. (2018). Penggunaan poster sebagai media komunikasi kesehatan. Komunikologi, 15, 8-14.

Susanto, D. (2020). Kasus Gangguan Jiwa di Indonesia Meningkat Selama Masa Pandemi. Media Indonesia. https://mediaindonesia.com/humaniora /352006/kasus-gangguan-jiwa-diindonesia-meningkat-selama-masapandemi

Ulya, Z., \& Iskandar, A. (2017). Pengaruh Pendidikan Kesehatan Dengan Media Poster Terhadap Pengetahuan Manajemen Hipertensi Pada Penderita Hipertensi. Jurnal Keperawatan Soedirman, $\quad$ 12(1), 38. https://doi.org/10.20884/1.jks.2017.12. 1.715

Wahyuni, N. (2020). Kesehatan Jiwa dan Resiliensi Sosial di Tengah Pandemi. https://www.theindonesianinstitute.com /kesehatan-jiwa-dan-resiliensi-sosialdi-tengah-pandemi/ 